\title{
Effect of Insulin, Catecholamines and Calcium Ions on Phospholipid Metabolism in Isolated White Fat-Cells
}

\author{
J. Adolfo GARCIAA-SÁINZ and John N. FAIN \\ Section of Physiological Chemistry, Division of Biology and Medicine, Brown University, \\ Providence, RI 02912, U.S.A.
}

(Received 6 August 1979)

\begin{abstract}
The incorporation of $\left[{ }^{32} \mathrm{P}\right] \mathrm{P}_{1}$ into phosphatidylinositol by rat fat-cells was markedly increased in the presence of adrenaline. Phosphatidic acid labelling was also increased, but to a lesser extent. These effects are due to $\alpha_{1}$-adrenergic stimulation since they were unaffected by propranolol, blocked by $\alpha$-blockers in the potency order prazosin $\ll$ phentolamine < yohimbine and mimicked by methoxamine. The $\alpha$-adrenergic stimulation of phosphatidylinositol labelling did not require extracellular $\mathrm{Ca}^{2+}$, which supports the hypothesis that an increased turnover of phosphatidylinositol is involved in $\alpha$-adrenergic activation of $\mathrm{Ca}^{2+}$ entry. Insulin and the ionophore A23187 gave a small increase in ${ }^{32} \mathrm{P}$ labelling of phosphatidylinositol in $\mathrm{Ca}^{2+}$-free medium containing 1 mM-EGTA. The increases due to insulin or ionophore A23187 were abolished if $2.5 \mathrm{mM}-\mathrm{Ca}^{2+}$ was added to medium containing EGTA. However, the increases in labelling of phosphatidylinositol due to $\alpha$-adrenergic amines were still evident in medium containing EGTA and $\mathrm{Ca}^{2+}$. Lipolytic agents such as corticotropin, dibutyryl cyclic AMP, adrenaline in the presence of phentolamine and isoproterenol decreased $\left.{ }^{32} \mathrm{P}\right] \mathrm{P}_{\mathrm{i}}$ incorporation into phosphatidylinositol, phosphatidylethanolamine and phosphatidic acid. This inhibitory effect may be secondary to accumulation of intracellular unesterified fatty acids, since it was decreased by incubating fewer cells in medium with 6 rather than $3 \%$ albumin and was restored by the addition of oleate to the medium. The incorporation of $\left[{ }^{32} \mathrm{P}\right] \mathrm{P}_{1}$ into phosphatidylcholine was unaffected by lipolytic agents. The data suggest that there is an inhibition of the synthesis of certain phospholipids in the presence of lipolytic agents, which may be secondary to intracellular accumulation of unesterified fatty acids.
\end{abstract}

In adipocytes $\beta$-adrenergic stimulators activate adenylate cyclase and lipolysis. The role of cyclic AMP as a second messenger for $\beta$-adrenergic stimulation is well established (Fain, 1979). Much less is known about $\alpha$-adrenergic effects. There is little effect of $\alpha$-adrenergic activation on glucose oxidation, cyclic AMP accumulation and lipolysis in rat fat-cells (Fain, 1979). However, Lawrence \& Larner (1978) reported that activation of rat adipocyte phosphorylase and inactivation of glycogen synthase are produced by stimulation of $\alpha$ adrenergic receptors. The inactivation of glycogen synthase by $\alpha$-adrenergic catecholamines was dependent on the presence of extracellular $\mathrm{Ca}^{2+}$ and may be secondary to increased entry of $\mathrm{Ca}^{2+}$ (Lawrence \& Larner, 1978).

$\mathrm{Ca}^{2+}$ has been postulated as a second messenger for $\alpha$-adrenergic stimulation (Fain, 1979) and has also been implicated in insulin action (Fraser, 1975).
In addition, an $\alpha$-adrenergic stimulation of ${ }^{42} \mathrm{~K}^{+}$ efflux from rat adipocytes has been seen, which may be secondary to an increase in cytosol $\mathrm{Ca}^{2+}$ (Perry $\&$ Hales, 1970). The mechanism by which $\alpha$ adrenergic agents increase influx of extracellular $\mathrm{Ca}^{2+}$ is not known. Activation of $\alpha$-adrenergic and muscarinic receptors is generally accompanied by increased incorporation of $\left[{ }^{32} \mathrm{P}\right] \mathrm{P}_{\mathrm{i}}$ into phosphatidylinositol and it has been suggested that phosphatidylinositol turnover may be involved in the mobilization of $\mathrm{Ca}^{2+}$ (Michell, 1975, 1979; Jones \& Michell, 1978).

Stein \& Hales (1972) reported that in rat fat-cells, adrenaline stimulates the incorporation of $\left[{ }^{32} \mathrm{P}\right] \mathrm{P}_{\mathbf{i}}$ into phosphatidylcholine and that incubation of fatcells with propranolol and adrenaline decreased the formation of phosphatidylcholine, but increased incorporation into phosphatidylethanolamine, phosphatidic acid, phosphatidylinositol and cardiolipin. 
De Torrontegui \& Berthet (1966) found that insulin increased the incorporation of $\left.{ }^{32} \mathrm{P}\right] \mathrm{P}_{1}$ from the medium into all fat-cell phospholipids, but especially phosphatidylinositol. The present experiments were designed to investigate the hormonal regulation of phospholipid metabolism in rat fat-cells with particular emphasis on the role of $\mathrm{Ca}^{2+}$.

\section{Materials and Methods}

\section{Chemicals}

Adrenaline, isoproterenol, ( \pm )-propranolol, insulin, glucagon, corticotropin and $N^{6} O^{2}$-dibutyryl cyclic AMP were obtained from Sigma Chemical Co., yohimbine from Nutritional Biochemicals, crude collagenase (Clostridium histolyticum) from Worthington Biochemical Corp. (lot CLS 48A281), bovine serum albumin (fraction V) from Armour Pharmaceutical Co. (lot S11709) and $\left[{ }^{32} \mathrm{P}\right] \mathrm{P}_{1}$ as orthophosphoric acid (carrier-free) from New England Nuclear. The following compounds were generously provided by the sources indicated: $(+)-$ propranolol and (-)-propranolol, Ayerst Laboratories; phentolamine, CIBA Pharmaceutical Company; ionophore A23187, Eli Lilly Co.; prazosin, Pfizer; methoxamine, Burroughs Wellcome. Enzymes and coenzymes for glycerol determination were obtained from Boehringer Mannheim. Other reagents were analytical grade of the best quality available.

\section{Preparation of adipocytes and assay of glycerol}

Female Sprague-Dawley rats (200-250g; Charles River CD strain) were fed laboratory chow ad libitum. White fat-cells were obtained by enzymic digestion of parametrial adipose tissue by the procedure of Rodbell (1964). Pooled adipose tissue (approx. 25g) from five to six rats was minced with scissors and placed in small plastic bottles. Each bottle, containing approx. $13 \mathrm{~g}$ of tissue and $20 \mathrm{ml}$ of Krebs-Ringer-Tris buffer supplemented with $3 \%$ albumin and $1 \mathrm{mg}$ of crude collagenase $/ \mathrm{ml}$, was incubated for $60 \mathrm{~min}$ at $37^{\circ} \mathrm{C}$ in an orbital shaker. Krebs-Ringer-Tris buffer of the following composition was used in all experiments: $120 \mathrm{mM}$ $\mathrm{NaCl} ; 1.4 \mathrm{~mm}-\mathrm{CaCl}_{2} ; 5.2 \mathrm{~mm}-\mathrm{KCl} ; 1.4 \mathrm{~mm}-\mathrm{MgSO}_{4}$; $5 \mathrm{~mm}$-Tris. The buffer was prepared daily and adjusted to $\mathrm{pH} 7.4$ at $37^{\circ} \mathrm{C}$, with $\mathrm{NaOH}$, after addition of albumin powder. At the end of $60 \mathrm{~min}$ digestion, cells were filtered through one layer of nylon chiffon and washed twice with albumin buffer. Glycerol was analysed as previously described (Fain et al., 1973). Fat-cells were counted with a light microscope as previously described (Malbon et al., 1978).

\section{Measurement of $\left[{ }^{32} \mathrm{P}\right] \mathrm{P}_{i}$ incorporation into phospholipids}

Fat-cells were incubated in plastic bottles containing $2 \mathrm{ml}$ of phosphate-free medium and $\left[{ }^{32} \mathrm{P}\right] \mathrm{P}_{1}$ at a concentration of $10 \mu \mathrm{Ci} / \mathrm{ml}$. Usually $2 \mathrm{ml}$ of packed cells (about $4 \times 10^{6}$ cells) was added to $2 \mathrm{ml}$ of medium. After incubation the cells were transferred to plastic tubes and centrifuged for $15 \mathrm{~s}$ in a clinical centrifuge. The medium was removed and a $50 \mu 1$ portion was used for glycerol determination. The cells were gently resuspended in $5 \mathrm{ml}$ of KrebsRinger-Tris buffer containing $1 \%$ albumin. The medium was removed and $10 \mathrm{ml}$ of chloroform/ methanol $(2: 1, \mathrm{v} / \mathrm{v})$ was added to the contents of each tube, which was then shaken and filtered through filter paper. The single-phase system obtained was separated by the addition of $5 \mathrm{ml}$ of $10 \mathrm{~mm}-\mathrm{KH}_{2} \mathrm{PO}_{4}$. The upper layer (aqueous phase) was discarded. The chloroform layer was washed again with $5 \mathrm{ml}$ of $10 \mathrm{mM}-\mathrm{KH}_{2} \mathrm{PO}_{4}$ in water. After removal of the upper phase, $1 \mathrm{~g}$ of silicic acid and $5 \mathrm{ml}$ of chloroform were added to adsorb phospholipids. The mixture was vortex-mixed for $1 \mathrm{~min}$ and centrifuged. The supernatant was decanted and the silicic acid granules were washed twice with $2.5 \mathrm{ml}$ of chloroform to remove triacylglycerols. The phospholipids were removed from the silicic acid by three extractions with $2.5 \mathrm{ml}$ of methanol. The methanol was evaporated in a vacuum centrifuge. The phospholipids were dissolved in chloroform/ methanol $(2: 1, \mathrm{v} / \mathrm{v})$, separated by two-dimensional t.l.c. on glass plates coated with silica gel $\mathrm{H}$ (Merck) as described by Fain \& Berridge (1979). The first solvent system contained chloroform/methanol/ water $/ 28 \% \mathrm{NH}_{3}(26: 14: 1: 1$, by vol. $)$ and the second solvent system chloroform/methanol/water/ acetic acid (75:25:3:7, by vol.).

In the studies shown in Tables 3-7 the phospholipids were separated by one-dimensional chromatography using only the first solvent system. This procedure was equally suitable for the separation of phosphatidylcholine, phosphatidylethanolamine and phosphatidylinositol. Phosphatidic acid could not be separated from phosphatidylserine, which resulted in a lower specific radioactivity for the phosphatidic acid area. However, since the uptake of radioactivity into phosphatidylserine is less than $6 \%$ of that into phosphatidic acid; the radioactivity in this spot is assumed to be phosphatidic acid. The uptake of $\left[{ }^{32} \mathrm{P}\right] \mathrm{P}_{1}$ into cardiolipin and sphingomyelin is only reported in Table 1 because no effects of hormones could be detected and the incorporation of radioactivity into these spots was small and quite variable. Cardiolipin and sphingomyelin were separated from the other phospholipids by one-dimensional chromatography.

Lipids were identified by using $\mathrm{I}_{2}$-vapour staining and by radioautography with $\mathrm{X}$-ray film. Phos- 
phatidic acid was detected by radioautography because the amount of this phospholipid was insufficient to be seen with $I_{2}$ staining. The phosphorus content of phospholipids was determined by the micromodification of the procedure of Bartlett (1959) after acid hydrolysis of silica-gel scrapings containing each individual phospholipid. Samples of the hydrolysate were counted to determine the amount of radioactivity present in each phospholipid.

Since some variability was observed from day to day in the incorporation of $\left[{ }^{22} \mathrm{P}\right] \mathrm{P}_{1}$ into phospholipids, the results are expressed as a percentage of control specific radioactivity of each phospholipid. Each experiment was repeated at least three times on different days and the results are expressed as means \pm S.E.M.

\section{Results}

\section{Composition and incorporation of $P_{i}$ into adipocytes}

Incorporation of $\left[{ }^{32} \mathrm{P}\right] \mathrm{P}_{1}$ into phospholipids was linear for at least $2 \mathrm{~h}$ (results not shown). A time period of $1 \mathrm{~h}$ was selected for the incubations in this report because at this time there is substantial incorporation of radioactive phosphate into major phospholipids (Table 1). The phospholipid composition of fat-cells (Table 1) resembles that of other tissues (White, 1973). Phosphatidylcholine and phosphatidylethanolamine contribute about $70 \%$ of the phosphate present in phospholipids. The incorporation of radioactive phosphate was primarily into phosphatidylcholine, with lesser amounts in phosphatidic acid and phosphatidylinositol (Table 1). Some incorporation of $\left[{ }^{32} \mathrm{P}\right] \mathrm{P}_{1}$ was seen in phosphatidylethanolamine, but there was very little in phosphatidylserine, cardiolipin or sphingomyelin. No clear-cut change in phospholipid composition was produced by any of the agents employed over the $1 \mathrm{~h}$ incubation used in the present studies.

\section{Effect of adrenergic amines on the incorporation of} $\left.{ }^{[32} P\right] P_{i}$ into phospholipids

Adrenaline produced marked changes in the incorporation of $\left[{ }^{32} \mathrm{P}\right] \mathrm{P}_{1}$ into phospholipids (Fig. 1).

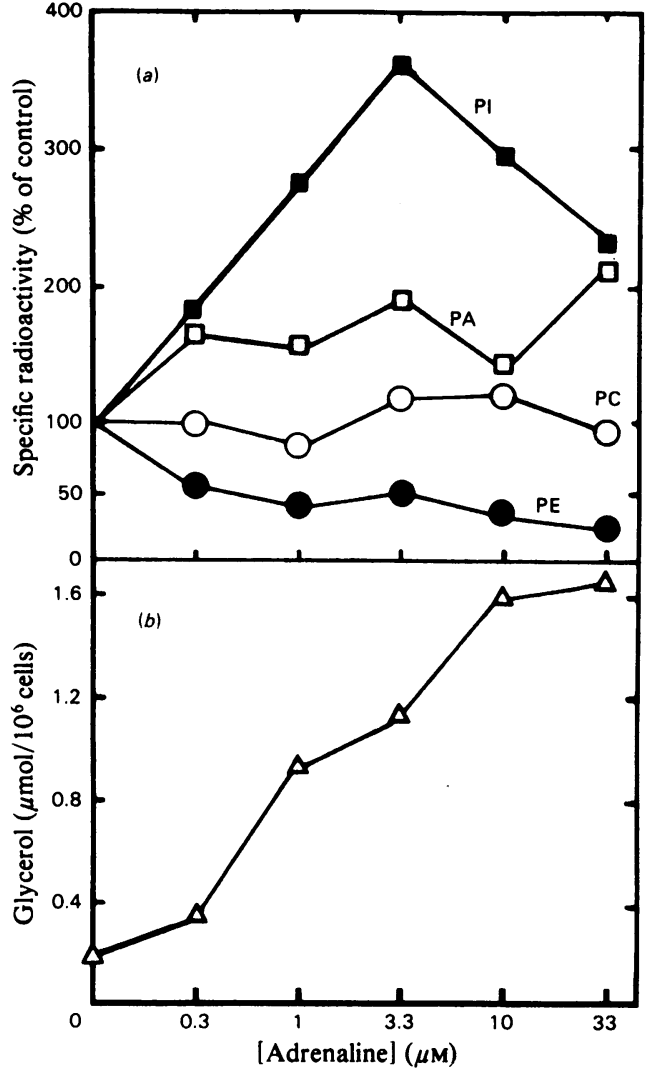

Fig. 1. Dose-response curve for effects of adrenaline on $\left.{ }^{[32} \mathrm{P}\right] \mathrm{P}_{t}$ incorporation into phospholipids and lipolysis The specific radioactivities of the phospholipid (c.p.m. $/ \mu \mathrm{g}$ of phosphate) under control conditions were similar to those in Table 1 and taken as $100 \%$. Values in the presence of various concentrations of adrenaline are shown as percentages of the control values without catecholamine. The values of $\left[{ }^{32} \mathrm{P}\right] \mathrm{P}_{1}$ uptake into phospholipids are shown in (a). Results for phosphatidylinositol (PI), phosphatidic acid (PA), phosphatidylcholine (PC) and phosphatidylethanolamine (PE) are means for three separate experiments. The effect of adrenaline on lipolysis is shown in $(b)$.

Table 1. Incorporation of $\left[{ }^{32} P \mid P_{i}\right.$ into phospholipids of isolated fat-cells

Fat-cells $\left(4 \times 10^{6}\right)$ were incubated for $60 \mathrm{~min}$ in $2 \mathrm{ml}$ of buffer containing $3 \%$ albumin and [ $\left.{ }^{32} \mathrm{P}\right] \mathrm{P}_{1}$ at a concentration of $10 \mu \mathrm{Ci} / \mathrm{ml}$. The results are expressed as means \pm S.E.M. for eight different experiments. The recovered phospholipids contained $8.1 \pm 1.0 \mu \mathrm{g}$ of phosphate; the total incorporation was $19440 \pm 2600$ c.p.m. (means \pm S.E.M.).

$\begin{array}{lccc} & \begin{array}{c}\text { Phosphate } \\ \text { (\% of total) }\end{array} & \begin{array}{c}\text { Incorporation of }\left[{ }^{32} \mathrm{P}\right] \mathbf{P}_{\mathbf{i}} \\ \text { (\% of total) }\end{array} & \begin{array}{c}\text { Specific radioactivity } \\ \text { (c.p.m. } / \mu \text { g of } P_{\mathbf{i}} \text { ) }\end{array} \\ \text { Phosphatidylethanolamine } & 33.0 \pm 1.9 & 4.7 \pm 0.6 & 440 \pm 100 \\ \text { Phosphatidylcholine } & 39.1 \pm 2.0 & 56.6 \pm 6.9 & 3795 \pm 840 \\ \text { Phosphatidylinositol } & 8.5 \pm 0.8 & 13.6 \pm 3.2 & 3825 \pm 580 \\ \text { Phosphatidic acid } & 2.3 \pm 0.4 & 20.9 \pm 3.9 & 25700 \pm 3000 \\ \text { Phosphatidylserine } & 7.3 \pm 0.7 & 1.3 \pm 0.4 & 420 \pm 100 \\ \text { Cardiolipin } & 6.2 \pm 0.6 & 0.7 \pm 0.1 & 325 \pm 45 \\ \text { Sphingomyelin } & 3.6 \pm 0.5 & 1.4 \pm 0.2 & 900 \pm 185\end{array}$


The incorporation of label into phosphatidylinositol was increased by low concentrations of adrenaline $(1-3.3 \mu \mathrm{M})$. Higher concentration of adrenaline did not result in any further stimulation of phosphatidylinositol labelling. Phosphatidic acid labelling was only slightly stimulated by adrenaline (Fig. 1). The specific radioactivity of phosphatidylcholine was not appreciably modified by adrenaline, whereas that of phosphatidylethanolamine was markedly decreased. An inverse relationship was observed between lipolysis and the specific radioactivity of phosphatidylethanolamine (Fig. 1).

Adrenaline is both an $\alpha$ - and $\beta$-adrenergic agonist. To determine which actions of adrenaline were due to $a$-stimulation and which to $\beta$-activation, pure $\alpha$ - and $\beta$-adrenergic agonists and antagonists were employed. The $\alpha$-adrenergic blocking agent phentolamine did not affect significantly the incorporation of label into phospholipids or lipolysis due to adrenaline (Table 2). However, the marked increase in phosphatidylinositol labelling produced by adrenaline was blocked by phentolamine. There was actually a decrease in the specific radioactivity of phosphatidylinositol and all other phospholipids in the presence of adrenaline plus phentolamine (Table 2). Similar results were seen with isoproterenol, a $\beta$-adrenergic agonist, except that phosphatidylcholine was unaltered (Table 2). Propranolol, a $\beta$-adrenergic blocking agent, alone increased the incorporation of $\left[{ }^{32} \mathrm{P}\right] \mathrm{P}_{\mathbf{1}}$ into phosphatidylinositol and phosphatidic acid and this effect was additive to that of adrenaline (Table 2). These results suggest that the increase in phosphatidylinositol labelling observed with adrenaline is an $\alpha$-action. In support of this conclusion, the $\alpha$-adrenergic agonist methoxamine also increased the specific radioactivity of phosphatidylinositol (Table 2).
Characterization of the $\alpha$-receptor involved in the phosphatidylinositol effect in fat-cells.

Considerable evidence indicates that $\alpha$-receptors can be divided into at least two subclasses, i.e. $\alpha_{1}$ and $\alpha_{2}$ (Berthelsen \& Pettinger, 1977; U'Prichard et al., 1978; Hoffman et al., 1979; Wood et al., 1979). The use of selective agonists and antagonists have clarified this point. It has been shown that phentolamine is an $\alpha$-adrenergic antagonist equipotent at $\alpha_{1^{-}}$and $\alpha_{2}$-receptors (Hoffman et al., 1979), prazosin is 3-4 orders of magnitude more potent at $\alpha_{1}$ - than at $\alpha_{2}$-receptors (U'Prichard et al., 1978; Hoffman et al., 1979) and yohimbine has a 500-fold greater affinity for $\alpha_{2}$-than for $\alpha_{1}$-receptors (Hoffman et al., 1979). On the other hand, methoxamine is considered an $\alpha_{1}$-agonist, whereas clonidine is $\alpha_{2}$ (Berthelson \& Pettinger, 1977).

The action of $\alpha$-adrenolytic agents on the adrenaline-mediated increase in phosphatidylinositol labelling was tested (Table 3). Prazosin completely blocked the effect of adrenaline $(10 \mu \mathrm{M})$ at a concentration of $0.1 \mu \mathrm{M}$, whereas $100 \mu \mathrm{M}$-yohimbine or $10 \mu \mathrm{M}$-phentolamine were required to produce the same inhibition. $\alpha$-Adrenergic blockers did not modify either the basal incorporation of $\left.{ }^{32} \mathrm{P}\right] \mathrm{P}_{1}$ into phosphatidylinositol (Table 3) or adrenaline-induced lipolysis (results not shown). On the other hand, methoxamine produced a 2 -fold increase in phosphatidylinositol labelling (Table 2), whereas clonidine $(1-100 \mu \mathrm{M})$ produced no effect on this parameter (results not shown).

Effect of lipolytic agents on the incorporation of $P_{i}$ into phospholipids and role of unesterified fatty acids

The effects of non-adrenergic lipolytic agents are shown in Table 4. Both corticotropin and dibutyryl

Table 2. Effect of $\alpha$-and $\beta$-adrenergic agonists and antagonists on the incorporation of $\left[{ }^{32} P\right] P$ into fat-cell phospholipids Fat-cells $\left(4 \times 10^{6}\right)$ were incubated for $60 \mathrm{~min}$ in $2 \mathrm{ml}$ of buffer containing $3 \%$ albumin and $10 \mu \mathrm{Ci}$ of $\left[{ }^{32} \mathrm{P} \mid \mathrm{P}_{\mathrm{i}} / \mathrm{ml}\right.$. The results are expressed as means \pm S.E.M. for three experiments performed on different days. The effects of added agents are expressed as a percentage of the control value for uptake of ${ }^{32} \mathrm{P}$ and as the absolute values for glycerol release.

\section{Treatment}

None

Adrenaline $(3.3 \mu \mathrm{M})$

Phentolamine $(30 \mu \mathrm{M})$

Adrenaline $(3.3 \mu \mathrm{M})+$ phentolamine

Isoproterenol $(10 \mu \mathrm{M})$

( \pm )-Propranolol $(30 \mu \mathrm{M})$

Adrenaline $(3.3 \mu \mathrm{M})+( \pm)$-propranolol

Methoxamine $(100 \mu \mathrm{M})$
Specific radioactivity

\begin{tabular}{|c|c|c|c|c|}
\hline \multicolumn{4}{|c|}{ Specific radioactivity } & \multirow[b]{2}{*}{$\begin{array}{l}\text { Glycerol release } \\
\text { (nmol } / 10^{6} \text { cells) }\end{array}$} \\
\hline $\begin{array}{l}\text { Phosphatidyl- } \\
\text { ethanolamine }\end{array}$ & $\begin{array}{l}\text { Phosphatidyl- } \\
\text { choline }\end{array}$ & $\begin{array}{l}\text { Phosphatidyl- } \\
\text { inositol }\end{array}$ & $\begin{array}{l}\text { Phosphatidic } \\
\text { acid }\end{array}$ & \\
\hline $335 \pm 85$ & $\begin{array}{l}\text { (c.p.m./A } \\
3635 \pm 830\end{array}$ & $\begin{array}{l}\left.\mu \mathrm{g} \text { of } P_{1}\right) \\
\quad 3505 \pm 915\end{array}$ & $28745 \pm 3390$ & $150 \pm 10$ \\
\hline $\begin{array}{c}48 \pm 25 \\
121 \pm 24 \\
30 \pm 15 \\
24 \pm 9 \\
147 \pm 31 \\
193 \pm 33 \\
110 \pm 20\end{array}$ & $\begin{array}{c}\quad \% \text { of } c \\
120 \pm 36 \\
96 \pm 2 \\
67 \pm 5 \\
100 \pm 14 \\
98 \pm 15 \\
79 \pm 3 \\
84 \pm 17\end{array}$ & $\begin{array}{l}\text { ontrol) } \\
281 \pm 94 \\
146 \pm 45 \\
37 \pm 13 \\
34 \pm 16 \\
340 \pm 146 \\
1171 \pm 241 \\
203 \pm 17\end{array}$ & $\begin{array}{r}141 \pm 14 \\
106 \pm 45 \\
68 \pm 21 \\
53 \pm 14 \\
225 \pm 87 \\
297 \pm 20 \\
154 \pm 81\end{array}$ & $\begin{array}{c}1275 \pm 163 \\
165 \pm 35 \\
1325 \pm 320 \\
1535 \pm 95 \\
220 \pm 45 \\
205 \pm 35 \\
175 \pm 15\end{array}$ \\
\hline
\end{tabular}


cyclic AMP produced significant decreases in the specific radioactivities of phosphatidylethanolamine and phosphatidylinositol. The specific radioactivity of phosphatidic acid was decreased by corticotropin and $2.5 \mathrm{mM}$, but not $0.5 \mathrm{~mm}$-dibutyryl cyclic AMP (Table 4). The incorporation of $\left[{ }^{32} \mathrm{P}\right] \mathrm{P}_{1}$ into phosphatidylcholine was not affected by the lipolytic agents (Table 4). The effects of corticotropin and dibutyryl cyclic AMP were identical with those of isoproterenol (Table 4).

The accumulation of unesterified fatty acids intracellularly can uncouple oxidative phosphorylation (Angel et al., 1971). Since large amounts of cells were employed in these studies, it is possible that the unesterified fatty acids released by adipocytes in the presence of lipolytic agents may saturate the binding sites for unesterified fatty acids on

Table 3. Effect of $\alpha$-adrenergic antagonists on the action of adrenaline and methoxamine on the incorporation of radioactive phosphate into phosphatidylinositol Fat-cells $\left(2 \times 10^{6}\right)$ were incubated for $60 \mathrm{~min}$ in $2 \mathrm{ml}$ of medium containing $6 \%$ albumin and $10 \mu \mathrm{Ci}$ of $\left[{ }^{32} \mathrm{P}\right] \mathrm{P}_{\mathrm{i}} / \mathrm{ml}$. Basal specific radioactivity of phosphatidylinositol was $5975 \pm 380$ c.p.m./ $\mu \mathrm{g}$ of $P_{1}$ (mean \pm S.E.M. for four experiments). The values are means \pm S.E.M. for four experiments.

\section{Specific radioactivity}

(\% of control)

\begin{tabular}{lcc}
\cline { 2 - 3 } \multicolumn{1}{c}{ Antagonist } & Basal & Adrenaline $(10 \mu \mathrm{M})$ \\
None & 100 & $490 \pm 50$ \\
Prazosin $(0.01 \mu \mathrm{M})$ & & $355 \pm 64$ \\
Prazosin $(0.1 \mu \mathrm{M})$ & $105 \pm 10$ & $108 \pm 10$ \\
Prazosin $(1 \mu \mathrm{M})$ & $102 \pm 1$ & $73 \pm 5$ \\
Yohimbine $(1 \mu \mathrm{M})$ & & $437 \pm 66$ \\
Yohimbine $(10 \mu \mathrm{M})$ & $106 \pm 12$ & $313 \pm 71$ \\
Yohimbine $(100 \mu \mathrm{M})$ & $104 \pm 14$ & $114 \pm 17$ \\
Phentolamine $(1 \mu \mathrm{M})$ & & $335 \pm 86$ \\
Phentolamine $(10 \mu \mathrm{M})$ & $94 \pm 5$ & $83 \pm 9$
\end{tabular}

albumin and accumulate intracellularly; such accumulation of unesterified fatty acids may be responsible for the decreased incorporation of [ $\left.{ }^{32} \mathrm{P}\right] \mathrm{P}_{1}$ into phospholipids. To test this point, fewer cells $\left(2 \times 10^{6}\right)$ were incubated in medium containing larger concentrations of albumin (6\%). Under these conditions the decrease in phospholipid labelling produced by lipolytic agents was avoided (Table 5). The effects of lipolytic agents on $\left.{ }^{32} \mathrm{P}\right] \mathrm{P}_{1}$ incorporation were restored if oleate was added to the medium (Table 5). Basal and hormone-stimulated lipolysis were higher if fewer cells were incubated in the medium with a higher concentration of albumin (compare Tables 2 and 4 with Table 5). The activation of lipolysis due to hormones, but not that due to dibutyryl cyclic AMP, was decreased by the addition of oleate (Table 5). Basal incorporation of $\left[{ }^{32} \mathrm{P}\right] \mathrm{P}_{1}$ into phospholipids was not significantly affected by increasing the concentration of albumin in the medium or adding unesterified fatty acids (Table 5).

\section{Effect of propranolol on the incorporation of $P_{i}$ into phospholipids}

In an effort to clarify the action of propranolol on the incorporation of phosphate into phosphatidylinositol, the action of the optical isomers of propranolol was tested. The $(+)$-isomer does not block the lipolytic response due to adrenaline (Table 6). However, (+)-propranolol increased phosphatidylinositol labelling and this action was additive to that of adrenaline (Table 6). The (-)-isomer of propranolol produced the same effects as the racemic mixture on lipolysis and incorporation of $\left[{ }^{32} \mathrm{P}\right] \mathrm{P}_{1}$ into phosphatidylinositol (cf. Tables 2 and 6).

Effect of insulin, adenosine, and ionophore A23187 on the incorporation of $P_{i}$ into phospholipids

Adenosine, phenylisopropyladenosine and carbamoylcholine did not modify the incorporation of

Table 4. Effect of corticotropin and dibutyryl cyclic AMP on the incorporation of $\left[{ }^{32} P\right] P_{1}$ into fat-cell phospholipids Fat-cells $\left(4 \times 10^{6}\right)$ were incubated for $60 \mathrm{~min}$ in $2 \mathrm{ml}$ of buffer containing $3 \%$ albumin and $10 \mu \mathrm{Ci}$ of $\left[{ }^{32} \mathrm{P}\right] \mathrm{P}_{1} / \mathrm{ml}$. The values are means \pm S.E.M. for three separate experiments.

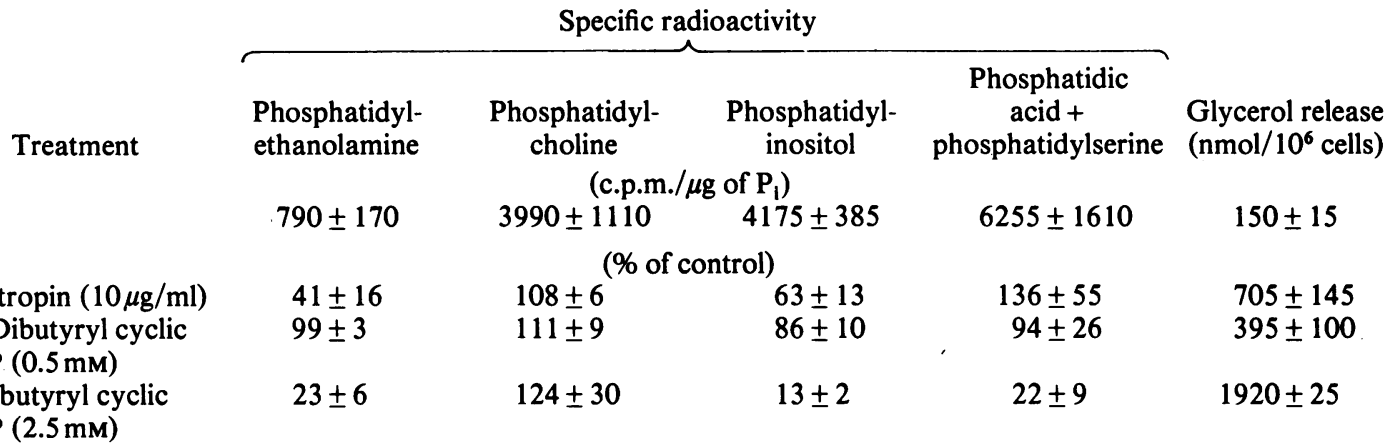

Vol. 186 
[ $\left.{ }^{32} \mathrm{P}\right] \mathrm{P}_{1}$ into any phospholipid (results not shown). In three experiments the phosphatidylinositol specific radioactivity of cells incubated in regular buffer containing $\mathrm{Ca}^{2+}$ as a percentage of the control value was 196, 254, and 358 in the presence of insulin and 121,156 , and 234 in the presence of ionophore

Table 5. Effect of $6 \%$ albumin and unesterified fatty acids on the changes in incorporation of $\left[{ }^{32} P\right] P_{l}$ into fat-cell phospholipids by lipolytic agents

Fat-cells $\left(2 \times 10^{6}\right)$ were incubated for $60 \mathrm{~min}$ in $3 \mathrm{ml}$ of buffer containing $6 \%$ albumin either without or with added oleate. Unesterified-fatty acid-to-albumin molar ratio was 0.8 for $6 \%$ albumin without and 2.6 for $6 \%$ albumin with added oleate. The values are means \pm S.E.M. for three experiments.

Specific radioactivity

Treatment

None

Adrenaline $(3.3 \mu \mathrm{M})$

Adrenaline $(3.3 \mu \mathrm{M})+$ phentolamine $(30 \mu \mathrm{M})$

Isoproterenol $(10 \mu \mathrm{M})$

Corticotropin $(10 \mu \mathrm{g} / \mathrm{ml})$

$\mathrm{N}^{6} \mathrm{O}^{2}$-Dibutyryl

cyclic AMP $(2.5 \mu \mathrm{M})$

None

Adrenaline (3.3 $\mu \mathrm{M})$

Adrenaline $(3.3 \mu \mathrm{M})+$ phentolamine $(30 \mu \mathrm{M})$

Isoproterenol $(10 \mu \mathrm{M})$

Corticotropin $(10 \mu \mathrm{g} / \mathrm{ml})$

$N^{6} \mathrm{O}^{2}$-Dibutyryl

cyclic AMP $(2.5 \mu \mathrm{M})$ $\begin{array}{llcc}\text { Added } & \text { Phosphatidyl- } & \text { Phosphatidyl- } & \text { Phosphatidyl- } \\ \text { oleate } & \text { ethanolamine } & \text { choline } & \text { inositol }\end{array}$

Phosphatidic

acid + phosphatidylserine

Glycerol release (c.p.m. $/ \mu$ g of $P_{1}$ )

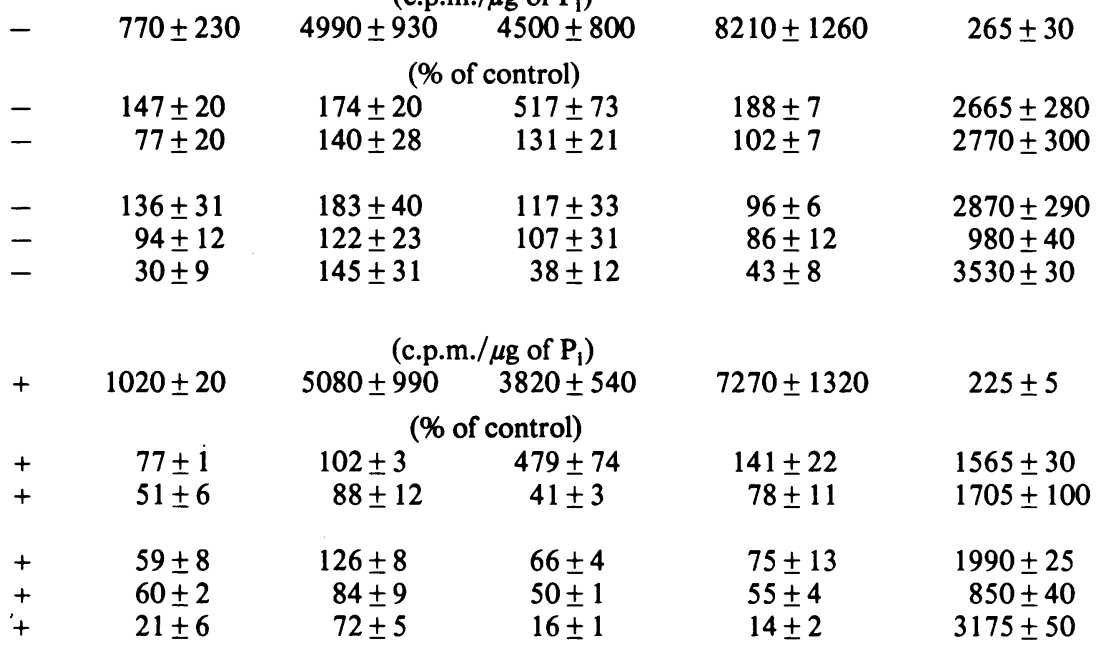

Table 6. Effect of adrenaline and propranolol on the incorporation of $\left[{ }^{32} \mathrm{P}\right] \mathrm{P}_{i}$ into fat-cell phospholipids Fat-cells $\left(4 \times 10^{6}\right)$ were incubated for $60 \mathrm{~min}$ in $2 \mathrm{ml}$ of buffer containing $3 \%$ albumin and $10 \mu \mathrm{Ci}$ of $\left[{ }^{32} \mathrm{P}\right] \mathrm{P}_{1} / \mathrm{ml}$. The values are means \pm S.E.M. for three paired experiments.

\section{Treatment}

None

Adrenaline $(3.3 \mu \mathrm{M})$

(+)-Propranolol $(10 \mu \mathrm{M})$

Adrenaline $(3.3 \mu \mathrm{M})+$

$(+)$-propranolol $(10 \mu \mathrm{M})$

(+)-Propranolol $(30 \mu \mathrm{M})$

Adrenaline $(3.3 \mu \mathrm{M})+$ (+)-propranolol $(30 \mu \mathrm{M})$

(-)-Propranolol $(10 \mu \mathrm{M})$

Adrenaline $(3.3 \mu \mathrm{M})+$ (-)-propranolol $(10 \mu \mathrm{M})$

(-)-Propranolol $(30 \mu \mathrm{M})$

Adrenaline $(3.3 \mu \mathrm{M})+$ (-)-propranolol $(30 \mu \mathrm{M})$
Specific radioactivity

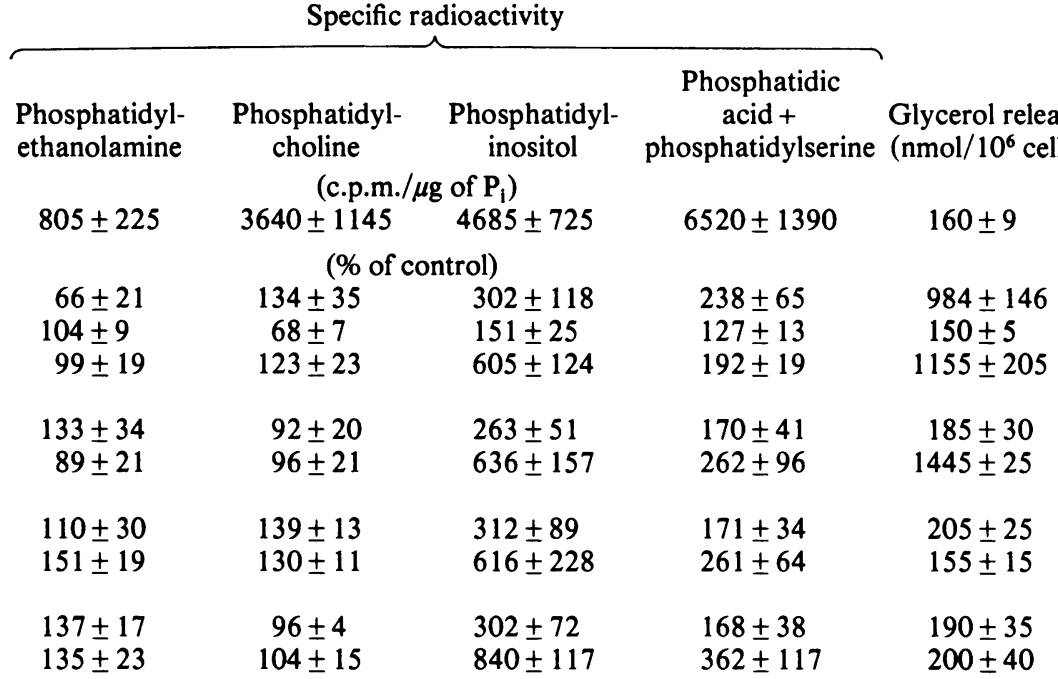


A23187. These results are similar to those shown in Table 7 for cells incubated in $\mathrm{Ca}^{2+}$-free buffer containing $1 \mathrm{mM}$-EGTA. However, insulin increased slightly the labelling of all phospholipids in regular buffer (results not shown).

Role of $\mathrm{Ca}^{2+}$ in the labelling of phospholipids with $P_{i}$

The role of extracellular $\mathrm{Ca}^{2+}$ in the action of $\alpha$-adrenergic agents, propranolol, insulin and ionophore A23187 on phospholipid labelling was tested by incubating the cells in medium with or without added $\mathrm{Ca}^{2+}$ in which $1 \mathrm{mM}$-EGTA was present. The specific radioactivity of phosphatidylinositol was lower in cells incubated in $\mathrm{Ca}^{2+}$-free buffer containing $1 \mathrm{mM}$-EGTA (the values for cells incubated in the absence of $\mathrm{Ca}^{2+}$ were 44,72 , and $82 \%$ of those in the presence of $\mathrm{Ca}^{2+}$ for the three experiments shown in Table 7). Incubation of fat-cells in the absence of $\mathrm{Ca}^{2+}$ and presence of 1 mM-EGTA did not decrease but actually enhanced the increases due to insulin and ionophore $\mathrm{A} 23187$ of $\left[{ }^{32} \mathrm{P}\right] \mathrm{P}_{1}$ incorporation into phosphatidylinositol (Table 7). The values for cells incubated with insulin as a percentage of the control value were 367,197 and 208 in the absence of $\mathrm{Ca}^{2+}$ and 66,83 and 92 in the presence of $\mathrm{Ca}^{2+}$ for the three experiments shown in Table 7. Similarly the values for cells incubated with ionophore A23187 as a percentage of the control value were 236, 201 and 195 in the absence of $\mathrm{Ca}^{2+}$ and 74, 60 and 79 in the presence of $\mathrm{Ca}^{2+}$. These data clearly indicate that if fat-cells are incubated with 1 mM-EGTA and $\mathrm{Ca}^{2+}$, the stimulation by both insulin and ionophore A23187 of phosphatidylinositol labelling that is seen in regular buffer or $\mathrm{Ca}^{2+}$-free buffer plus EGTA is lost.

The effects of $\alpha$-catecholamines and propranolol were not dependent on extracellular $\mathrm{Ca}^{2+}$. The increases in specific radioactivity of phosphatidylinositol due to $30 \mu \mathrm{M}$-propranolol as a percentage of the control values were 217,282 , and 204 for cells incubated in the absence of $\mathrm{Ca}^{2+}$ and 125,120 and 217 for cells incubated with $\mathrm{Ca}^{2+}$ for the studies shown in Table 7. The increases due to methoxamine or adrenaline in the presence of propranolol were unaffected by EGTA or EGTA plus $\mathrm{Ca}^{2+}$ (Table 7).

Recently, Hirata et al. (1979) reported that $\beta$ adrenergic agonists increase the methylation of phospholipids in rat reticulocyte 'ghosts'. The possibility that the decrease in the amount of labelled phosphatidylethanolamine might be due in part to its conversion into phosphatidylcholine was studied by incubating cells in medium containing $\mathrm{L}-\left[\mathrm{Me}^{3} \mathrm{H}\right]$ methionine. No increase in the incorporation of ${ }^{3} \mathrm{H}$ was observed with $\beta$-adrenergic amines. In fact, in two of the three experiments performed a small decrease was produced (results not shown).

Table 7. Effect of $\mathrm{Ca}^{2+}$ on the actions of $\alpha$-adrenergic agents, insulin and ionophore A23187 on the incorporation of $\left.{ }^{32} P\right] P_{i}$ into fat-cell phospholipids

Fat-cells $\left(4 \times 10^{6}\right)$ were incubated for $60 \mathrm{~min}$ in $2 \mathrm{ml}$ of buffer containing $3 \%$ albumin, $1 \mathrm{mM}$-EGTA and $10 \mu \mathrm{Ci}$ of $\left.{ }^{[2} \mathrm{P}\right] \mathrm{P}_{\mathrm{i}} / \mathrm{ml}$ either without or with $2.5 \mathrm{mM}-\mathrm{Ca}^{2+}$. The values are means \pm S.E.M. for three paired experiments.

\begin{tabular}{|c|c|c|c|c|c|}
\hline \multirow{3}{*}{ Treatment } & \multirow{3}{*}{$\begin{array}{c}\begin{array}{c}\text { Added } \\
\mathrm{CaCl}_{2} \\
(\mathrm{~mm})\end{array} \\
0\end{array}$} & \multicolumn{4}{|c|}{ Specific radioactivity } \\
\hline & & $\begin{array}{l}\text { Phosphatidyl- } \\
\text { ethanolamine }\end{array}$ & $\begin{array}{l}\text { Phosphatidyl- } \\
\text { choline }\end{array}$ & $\begin{array}{l}\text { Phosphatidyl- } \\
\text { inositol }\end{array}$ & $\begin{array}{l}\text { Phosphatidic } \\
\text { acid + phospha- } \\
\text { tidylserine }\end{array}$ \\
\hline & & $680 \pm 240$ & $\begin{array}{l}\text { (c.p.m./ } \\
4240 \pm 1160\end{array}$ & $\begin{array}{l}\left.\mu \mathrm{g} \text { of } P_{1}\right) \\
\quad 4450 \pm 1150\end{array}$ & $8375 \pm 3645$ \\
\hline $\begin{array}{l}\text { ol }(30 \mu \mathrm{M}) \\
3 \mu \mathrm{M})+( \pm) \text {-propranolol }(30 \mu \mathrm{M}) \\
\left(100 \mu_{\mathrm{M}}\right) \\
\text { units } / \mathrm{ml}) \\
3187\left(10 \mu_{\mathrm{M}}\right)\end{array}$ & $\begin{array}{l}0 \\
0 \\
0 \\
0 \\
0\end{array}$ & $\begin{array}{l}121 \pm 21 \\
135 \pm 33 \\
161 \pm 21 \\
149 \pm 30 \\
132 \pm 16\end{array}$ & $\begin{array}{c}\quad(\% \text { of } \\
77 \pm 17 \\
113 \pm 24 \\
117 \pm 21 \\
135 \pm 6 \\
70 \pm 27\end{array}$ & $\begin{array}{l}\text { ontrol) } \\
234 \pm 24 \\
404 \pm 66 \\
239 \pm 26 \\
257 \pm 55 \\
210 \pm 13\end{array}$ & $\begin{array}{l}157 \pm 7 \\
181 \pm 36 \\
175 \pm 29 \\
207 \pm 7 \\
200 \pm 47\end{array}$ \\
\hline & 2.5 & \multicolumn{4}{|c|}{ (c.p.m. $/ \mu \mathrm{g}$ of $\mathrm{P}_{\mathrm{i}}$ ) } \\
\hline $\begin{array}{l}\text { ol }(30 \mu \mathrm{M}) \\
3 \mu \mathrm{M})+( \pm) \text {-propranolol }(30 \mu \mathrm{M}) \\
(100 \mu \mathrm{M}) \\
\text { units } / \mathrm{ml}) \\
3187(10 \mu \mathrm{M})\end{array}$ & $\begin{array}{l}2.5 \\
2.5 \\
2.5 \\
2.5 \\
2.5\end{array}$ & $\begin{array}{c}108 \pm 17 \\
145 \pm 31 \\
74 \pm 13 \\
85 \pm 7 \\
77 \pm 15\end{array}$ & $\begin{aligned} & \text { (\% of } c \\
& 76 \pm 6 \\
& 79 \pm 3 \\
& 77 \pm 18 \\
& 100 \pm 14 \\
& 80 \pm 14\end{aligned}$ & $\begin{array}{l}\text { ontrol) } \\
\qquad \begin{array}{c}154 \pm 31 \\
440 \pm 43 \\
169 \pm 11 \\
80 \pm 7 \\
71 \pm 5\end{array}\end{array}$ & $\begin{array}{c}118 \pm 19 \\
192 \pm 48 \\
121 \pm 30 \\
72 \pm 7 \\
85 \pm 11\end{array}$ \\
\hline
\end{tabular}

( \pm )-Propranolol $(30 \mu \mathrm{M})$

Adrenaline $(3.3 \mu \mathrm{M})+( \pm)$-propranolol $(30 \mu \mathrm{M})$

Methoxamine $(100 \mu \mathrm{M})$

Insulin $(200 \mu$-units $/ \mathrm{ml})$

Ionophore A23187 $(10 \mu \mathrm{M})$

None

(士)-Propranolol $(30 \mu \mathrm{M})$

Adrenaline $(3.3 \mu \mathrm{M})+( \pm)$-propranolol $(30 \mu \mathrm{M})$

Methoxamine $(100 \mu \mathrm{M})$

Insulin $(200 \mu$-units $/ \mathrm{ml})$

Ionophore A23187 $(10 \mu \mathrm{M})$
Added

$\mathrm{CaCl}_{2}$

0

Vol. 186 


\section{Discussion}

The present results indicate that the incorporation of $\left[{ }^{32} \mathbf{P}\right] \mathbf{P}_{1}$ into phosphatidylinositol is markedly increased by adrenaline. This is an $\alpha$-adrenergic effect, since it was not abolished by propranolol, but was blocked by prazosin, phentolamine and yohimbine and mimicked by methoxamine. In addition the order of potency of adrenolytic antagonists (prazosin $\gg$ phentolamine $>$ yohimbine) and the fact that this effect is mimicked by methoxamine, but not by clonidine, clearly indicate that the catecholamine receptor involved is an $\alpha_{1}$-receptor. Similar results have been seen in rat pineal glands, where prazosin was a potent inhibitor of the catecholamine-induced increases in phosphatidylinositol synthesis (Smith et al., 1979).

The $\alpha$-adrenergic increase in phosphatidylinositol labelling was also observed in $\mathrm{Ca}^{2+}$-free medium containing EGTA; this indicates that it is independent of extracellular $\mathrm{Ca}^{2+}$. Lawrence \& Larner (1978) reported that methoxamine was unable to inactivate adipocyte glycogen synthase in $\mathrm{Ca}^{2+}$-free medium containing EGTA. In addition, the cation ionophore A23187 mimicked this effect of methoxamine on glycogen synthase. Our data are consistent with the hypothesis that phosphatidylinositol metabolism plays an important role in $\mathrm{Ca}^{2+}$ gating (Michell, 1975; Berridge \& Fain, 1979; Fain \& Berridge, 1979). Alternatively, catecholamine effects on $\mathrm{Ca}^{2+}$ gating and phosphatidylinositol metabolism may be independent. However, there is a close association between $\alpha$-adrenergic regulation of phosphatidylinositol turnover and $\mathrm{Ca}^{2+}$ entry in many systems (Michell, 1975, 1979; Jones \& Michell, 1978).

Stein \& Hales (1974) found that insulin increased the incorporation of phosphate into rat fat-cell phospholipids, which was attributed to an increase in the specific radioactivity of ATP. The increase due to insulin in the labelling of all phospholipids in regular buffer could be due to changes in the specific radioactivity of ATP, as already shown by Stein \& Hales (1974). However, the increases in phosphatidylinositol labelling due to $\alpha$-adrenergic catecholamines are apparently unrelated to changes in the specific radioactivity of ATP, since similar increases were not seen in labelling of other phospholipids. The same argument applies to the inhibition of $\left[{ }^{32} \mathrm{P}\right] \mathrm{P}_{1}$ incorporation into certain phospholipids by agents that activate lipolysis including $\beta$-catecholamines. The only way to explain the effects of either $\alpha$ - or $\beta$-catecholamines on phospholipid labelling through changes in the specific radioactivity of ATP is to postulate separate ATP pools involved in the synthesis of each phospholipid.

In medium containing $1 \mathrm{~mm}$-EGTA plus $2.5 \mathrm{~mm}$ $\mathrm{Ca}^{2+}$ insulin did not increase the labelling of phos- phatidylinositol. However, we observed that under these conditions the ability of insulin to stimulate $\left[1-{ }^{14} \mathrm{C}\right]$ glucose oxidation and inhibit lipolysis was unaltered (results not shown). The explanation for these results is not apparent, but does indicate that the effects of $\alpha$-adrenergic agonists on phosphatidylinositol labelling occur by mechanisms separate from those involved in any effect of insulin or ionophore A23187 on phospholipid labelling.

The action of propranolol on phosphatidylinositol labelling seems to be independent of its ability to block $\beta$-adrenergic receptors since the $(+)$-isomer that is inactive in this respect produced nearly the same action as the active isomer on phosphatidylinositol labelling. This effect is independent of the presence of $\mathrm{Ca}^{2+}$ in the medium and is probably related to its local-anaesthetic properties. In fact local anaesthetics and propranolol enhanced the incorporation of labelled phosphate into phosphatidylinositol and phosphatidic acid in rat pineal glands (Eichberg et al., 1978). These lipid-soluble cationic drugs exert their effects on phospholipid metabolism by redirection of synthesis towards phosphatidylinositol probably owing to inhibition of phosphatidate phosphohydrolase (Allan \& Michell, 1975; Brindley \& Bowley, 1975; Eichberg et al., 1978).

The ability of lipolytic agents to decrease the labelling of all phospholipids may be related to an intracellular accumulation of unesterified fatty acids, since it was prevented by increasing the concentration of albumin in the medium and the presence of medium to which fatty acids were added restored it. The ability of adrenaline to decrease the incorporation of $\left[{ }^{32} \mathrm{P}\right] \mathrm{P}_{1}$ into phosphatidylethanolamine was not observed in the presence of (+)propranolol. No clear explanation exists to this finding, but it may be related to the local-anaesthetic properties of this compound.

Stein \& Hales (1972) reported that adrenaline markedly increased the incorporation of $\left[{ }^{32} \mathbf{P}\right] \mathbf{P}_{1}$ into phosphatidylcholine and this effect was blocked by propranolol. Stein $(1975,1977)$ subsequently reported that adrenaline had no effect on the specific radioactivity of ATP, markedly decreased ATP content and increased the incorporation of $\left[{ }^{32} \mathbf{P}\right] \mathrm{P}_{1}$ into CDP-choline, but not into CDP-ethanolamine. The decrease in ATP due to adrenaline in the experiments of Stein $(1975,1977)$ and Stein \& Hales (1972) may have activated cholinephosphotransferase, which is known to be activated in liver by a decrease in ATP (Sribney et al., 1976). Our results are different, since we saw no increase in the incorporation of $\left[{ }^{32} \mathrm{P}\right] \mathrm{P}_{1}$ into phosphatidylcholine in the presence of $\beta$-catecholamines or other lipolytic agents. However, it was interesting that under conditions in which the uptake of $\left[{ }^{32} \mathrm{P}\right] \mathrm{P}_{1}$ into phosphatidic acid, phosphatidylethanolamine and phos- 
phatidylinositol was markedly decreased by lipolytic agents there was little effect on phosphatidylcholine (Table 5). This suggests that the formation of this phospholipid is not regulated by the same factors that affect the other phospholipids.

J. A. G.-S. is an International Fellow sponsored by the N.I.H. (Fellowship no. 1FO 5 TWO2691-01). This work was supported by United States Public Health Service Research grants AM 10149 and AM 21470 from the National Institute of Arthritis, Metabolism and Digestive Diseases, National Institutes of Health. We thank Dr. Margaret E. M. Tolbert and Dr. Alice C. White for reading and criticizing the manuscript and Mrs. Gerlinde Celona for secretarial assistance.

\section{References}

Allan, D. \& Michell, R. H. (1975) Biochem. J. 148, 471-478

Angel, A., Desai, K. S. Halperin, M. L. (1971) J. Lipid Res. 12, 203-212

Bartlett, G. R. (1959) J. Biol. Chem. 234, 466-468

Berridge, M. J. \& Fain, J. N. (1979) Biochem. J. 178, 59-69

Berthelsen, S. \& Pettinger, W. A. (1977) Life Sci. 21, 595-606

Brindley, D. N. \& Bowley, M. (1975) Biochem. J. 148, 461-469

De Torrontegui, G. \& Berthet, J. (1966) Biochim. Biophys. Acta 116, 477-481

Eichberg, J., Killion, J., Guerrant, G. \& Hauser, G. (1978) in Cyclitols and Phosphoinositides (Wells, W. W. \& Eisenberg, F., eds.), pp. 183-199, Academic Press, New York

Fain, J. N. (1979) Biochem. Actions Horm. 7, in the press

Fain, J. N. \& Berridge, M. J. (1979) Biochem. J. 178, 45-58
Fain, J. N., Czech, M. P. \& Saperstein, R. (1973) in Methods in Investigative and Diagnostic Endocrinology, Peptide Hormones (Berson, S. A. \& Yalow, R. S., eds.), pp. 267-273, North Holland Publishing Co., Amsterdam

Fraser, T. R. (1975) Proc. R. Soc. Med. 68, 785-791

Hirata, F., Strittmatter, W. J. \& Axelrod, J. (1979) Proc. Natl. Acad. Sci. U.S.A. 76, 368-372

Hoffman, B. B., DeLean, A., Wood, C. L., Schocken, D. D. \& Lefkowitz, R. F. (1979) Life Sci. 24, 17391746

Jones, L. M. \& Michell, R. H. (1978) Biochem. Soc. Trans. 6, 673-688

Lawrence, J. C. \& Larner, J. (1978) Mol. Pharmacol. 14, 1079-1091

Malbon, C. C., Moreno, F. J., Cabelli, R. J. \& Fain, J. N. (1978) J. Biol. Chem. 253, 671-678

Michell, R. H. (1975) Biochim. Biophys. Acta 415, 81-147

Michell, R. H. (1979) Trends Biochem. Sci. 4, 128-131

Perry, M. C. \& Hales, C. N. (1970) Biochem. J. 117, 615-621

Rodbell, M. (1964) J. Biol. Chem. 239, 375-380

Smith, T. L., Eichberg, J. \& Hauser, G. (1979) Life Sci. 24, 2179-2184

Sribney, M., Knowles, C. L. \& Lyman, E. (1976) Biochem.J. 156, 507-511

Stein, J. M. (1975) Biochem. Pharmacol. 24, 1659-1662

Stein, J. M. (1977) Biochem. Pharmacol. 26, 531-541

Stein, J. M. \& Hales, C. N. (1972) Biochem. J. 128, 531-541

Stein, J. M. \& Hales, C. N. (1974) Biochim. Biophys. Acta 337, 41-49

U'Prichard, D., Charness, M. E., Robertson, D. \& Snyder, S. H. (1978) Eur. J. Pharmacol. 50, 87-89

White, D. A. (1973) in Form and Function of Phospholipids (Ansell, G. B., Hawthorne, J. N. \& Dawson, R. M. C., eds.), pp. 441-448, Elsevier Scientific Publishing Co., Amsterdam

Wood, C. L., Arnett, C. D., Clarke, W. R., Tasai, B. S. \& Lefkowitz, R. J. (1979) Biochem. Pharmacol. 28, $1277-1282$ 